\title{
Commentary: Perioperative acute kidney injury: Perfusion strategies should target it, but mortality might not change
}

\author{
William M. DeCampli, MD, PhD
}

\footnotetext{
From the Department of Cardiothoracic Surgery, Arnold Palmer Hospital for Children, Orlando, Fla; and the College of Medicine, University of Central Florida, Orlando, Fla.

Disclosures: Author has nothing to disclose with regard to commercial support.

Received for publication Nov 19, 2018; accepted for publication Nov 20, 2018; available ahead of print Dec 29, 2018.

Address for reprints: William M. DeCampli, MD, PhD, Cardiothoracic Surgery, Arnold Palmer Hospital for Children, 83 W. Miller St, Orlando, FL 32813 (E-mail: William.decampli@ucf.edu).

J Thorac Cardiovasc Surg 2019;158:502-3

$0022-5223 / \$ 36.00$

Copyright $(2) 2018$ by The American Association for Thoracic Surgery

https://doi.org/10.1016/j.jtcvs.2018.11.068
}

Many published studies have demonstrated an association between peri-operative acute kidney injury (AKI) and early and later morbidity and mortality. ${ }^{1,2}$ These studies have driven attempts to mitigate AKI incidence by using "goaldirected" intraoperative and postoperative strategies in adult cardiac surgery. ${ }^{3-5}$ One metric, investigated for more than a decade, is the global oxygen delivery $\left(\mathrm{DO}_{2} \mathrm{i}\right)$ during cardiopulmonary bypass (CPB), which, practically speaking, is proportional to the product of pump flow rate and hematocrit. Numerous studies have shown an association between AKI and such quantities as the nadir of $\mathrm{DO}_{2} \mathrm{i}$, the area bounded by the $\mathrm{DO}_{2} \mathrm{i}$-time curve $\left(\mathrm{AUCDO}{ }_{2}\right)$ and some "critical" threshold of $\mathrm{DO}_{2} \mathrm{i}$, duration of $\mathrm{DO}_{2} \mathrm{i}$ below such a threshold $\left(\mathrm{tDO}_{2} \mathrm{i}\right)$, and similar measures that use the ratio of $\mathrm{DO}_{2} \mathrm{i}$ and the carbon dioxide production index. In this issue of the Journal, Mukaida and coworkers ${ }^{6}$ report a similar study of 112 patients, in which they found an association between stage $1 \mathrm{AKI}$ and both $\mathrm{AUCDO}_{2}$ and $\mathrm{tDO}_{2} \mathrm{i}$, but not nadir of $\mathrm{DO}_{2} \mathrm{i}$, with a threshold of $300 \mathrm{~mL} /$ $\mathrm{min} / \mathrm{m}^{2}$. The incidence of AKI was $21 \%$. AKI was predicted with a sensitivity of $87 \%$ and a specificity of $49 \%$ if $\mathrm{tDO}_{2} \mathrm{i}$ was greater than 15 minutes.

Although Mukaida and coworkers ${ }^{6}$ did not prove it, they suggest (and appropriately so) that frequent, even continuous measurements of $\mathrm{DO}_{2} \mathrm{i}$ are preferable to periodic measurements to optimize renal perfusion. In their study, the cut point-15 minutes-for predicting AKI is less than the typical interval (20-30 minutes) in which perfusionists conventionally measure hematocrit. With the conventional strategy, the window of opportunity for intervening on low $\mathrm{DO}_{2} \mathrm{i}$ may thus be missed. The caveats of the study are as follows:

1. The threshold of $300 \mathrm{~mL} / \mathrm{min} / \mathrm{m}^{2}$ used by Mukaida and coworkers $^{6}$ was assigned on the basis of previous studies, rather than being determined from the data. The chosen value may not be the optimal one.

2. The patient cohort underwent $\mathrm{CPB}$ with near normothermia. The model results will change under conditions of hypothermia.

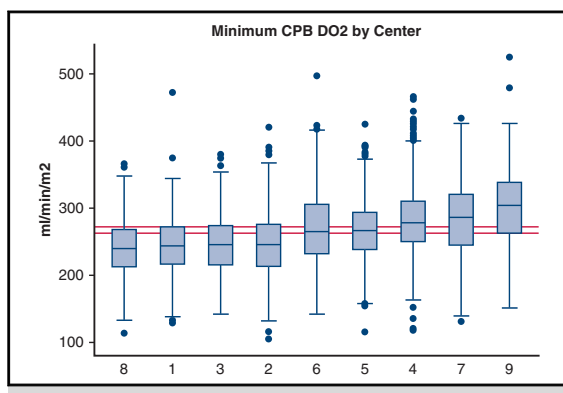

Variation in CPB oxygen delivery by institution. From Baker, ${ }^{8}$ used with permission.

Central Message

Goal-directed perfusion during cardiopulmonary bypass may reduce acute kidney injury, and it should be used. It may not reduce mortality, however.

See Article page 492

3. Many other operative and postoperative factors or events not appearing as covariates in the study of Mukaida and coworkers $^{6}$ could influence the risk for AKI.

4. The study was not powered to detect the effects of the intervention on more severe stages (II and III) of AKI.

Finally, peri-operative AKI may only be an epiphenomenon for stealthy underlying cardiovascular pathophysiology (CVPP), as suggested by (1) the observed association between mortality and "trivial" rises in creatinine $(<0.3 \mathrm{mg} / \mathrm{dL})$, (2) the observation that mortality is associated with transient rises in creatinine that normalize before hospital discharge, and (3) the absence of published comparisons of cause-specific mortality in patients with and without AKI. ${ }^{2,7}$ In statistical terminology, CVPP may be a confounder (or set of confounders), resulting in a spurious causal relationship between AKI and mortality. If so, then our efforts to reduce early and later mortality and morbidity after cardiac surgery solely by neutralizing the risk of perioperative AKI may be futile. The statistically rigorous way to work this out is by conducting a randomized study to estimate the following:

$$
\begin{aligned}
& \mathrm{P}[\text { mortality } \mid \operatorname{do}(\mathrm{AKI})] \\
& \quad=\sum \mathrm{P}(\text { mortality } \mid \mathrm{AKI}, \mathrm{CVP}) \mathrm{P}(\mathrm{CVP})
\end{aligned}
$$

where $d o(A K I)$ is the directly observed incidence of $\mathrm{AKI}$, $P(a \mid b)$ denotes conditional probability of event $a$ occurring, 
given condition $b$, and the sum is over all values of CVPP. The challenge would be how to define and measure CVPP. A compromise is simply to conduct a clinical trial to determine whether an intervention that prevents perioperative AKI actually decreases short- and long-term mortality and morbidity. In any case, "goal-directed" strategies against AKI are still warranted, because no injury is better than injury.

\section{References}

1. Brown JR, Cochran RP, Dacey LJ, Ross CS, Kunzelman KS, Dunton RF, et al; Northern New England Cardiovascular Disease Study Group. Perioperative increases in serum creatinine are predictive of increased 90-day mortality after coronary artery bypass graft surgery. Circulation. 2006;114(1 Suppl): I409-13.
2. Brown JR, Hisey WM, Marshall EJ, Likosky DS, Nichols EL, Everett AD, et al Acute kidney injury severity and long-term readmission and mortality after cardiac surgery. Ann Thorac Surg. 2016;102:1482-9.

3. Magruder JT, Crawford TC, Harness HL, Grimm JC, Suarez-Pierre A, Wierschke C, et al. A pilot goal-directed perfusion initiative is associated with less acute kidney injury after cardiac surgery. J Thorac Cardiovasc Surg. 2017;153:118-25.

4. Ranucci M, Johnson I, Willcox T, Baker RA, Boer C, Baumann A, et al. Goaldirected perfusion to reduce acute kidney injury: a randomized trial. J Thorac Cardiovasc Surg. 2018;156:1918-27.e2.

5. Groom RC. Is it time for goal-directed therapy in perfusion? J Extra Corpor Technol. 2017:49:P8-12.

6. Mukaida H, Matsushita S, Kuwaki K, Inotani T, Minami Y, Saigusa A, et al. Timedose response of oxygen delivery during cardiopulmonary bypass predicts acute kidney injury. J Thorac Cardiovasc Surg. 2019;158:492-9.

7. Liotta M, Olsson D, Sartipy U, Holzmann MJ. Minimal changes in postoperative creatinine values and early and late mortality and cardiovascular events after coronary artery bypass grafting. Am J Cardiol. 2014;113:70-5.

8. Baker RA. Variation in measurement and reporting of goal directed perfusion parameters. J Extra Corpor Technol. 2017;49:P2-7. 